\title{
リン吸着薬処方錠数の増加は服薬アドヒアランス低下 およびリン管理不良と関連する
}

\author{
伊藤 恭子1 永 野 伸 郎 $^{1,2,3}$ 高橋 伴彰 ${ }^{1}$ 石田 秀 岐 ${ }^{1}$ \\ 田ヶ原 綾香 ${ }^{1}$ 塚 田 美 保 ${ }^{1}$ 野原 ともい ${ }^{1}$ 岡 島 真 理 $^{1}$ \\ 野 原 惊 ${ }^{1}$ 星 綾 子 ${ }^{1}$ 溜井 紀子 ${ }^{1}$ 安藤 哲 郎 ${ }^{1}$ \\ 筒井貴朗 ${ }^{1}$ 新田 孝作 ${ }^{4}$ 佐 倉 宏 ${ }^{3}$ 小川哲也吕 \\ ${ }^{1}$ 日高会腎臓病治療センター ${ }^{2}$ 日高会日高学術研究センター \\ ${ }^{3}$ 東京女子医科大学東医療センター内科 ${ }^{4}$ 東京女子医科大学第 4 内科
}

キーワード：リン吸着薬, 処方錠数, 服薬アドヒアランス, 血清リン值

〈要旨〉

【目的】リン吸着薬の処方錠数が, 服薬アドヒアランスおよび血清リンに対する影響を検討する.【方法】リン吸着 薬処方中の外来維持血液透析患者 229 名にアンケート調査を実施し, 処方錠数および患者背景との関係を解析した. 【結果】リン吸着薬の月間処方錠数の中央值は 210 錠/月であり, 単刘処方者は $50 \%$ であった。処方錠数が多い群 は，年齢が若く，透析歴が長く，血清リンが高値であり，処方錠数は血清リンと正相関した．アドヒアランス不良 者は 30〜 40\%であり，「飲み忘れる」患者，「残薬がある」患者，「飲む量を減らしたい」患者は，処方錠数が多く， 血清リンが高値であった，処方錠数増加により，「残薬がある」，「量が多い・とても多い」と回答した患者が増加 し，アドヒアランス不良者は，「量が多い・とても多い」と感じる割合が多かった.【結語】リン吸着薬処方錠数の 増加にともない服薬アドヒアランスが低下し, 血清リン高值と関連する.

The prescription of a higher number of phosphate binder pills is associated with lower medication adherence and worse serum phosphorus control

Kyoko Ito', Nobuo Nagano, ${ }^{1,2,3}$, Tomoaki Takahashi', Hideki Ishida', Ayaka Tagahara', Miho Tsukada', Tomoi Nohara', Mari Okajima ${ }^{1}$, Atsushi Nohara ${ }^{1}$, Ayako Hoshi ${ }^{1}$, Noriko Tamei ${ }^{1}$, Tetsuo Ando', Takaaki Tsutsui ${ }^{1}$, Kosaku Nitta ${ }^{4}$, Hiroshi Sakura ${ }^{3}$, Tetsuya Ogawa ${ }^{1,3}$

${ }^{1}$ Kidney Disease and Dialysis Center, Hidaka-kai ; ${ }^{2}$ Hidaka Research Center, Hidaka-kai ; ${ }^{3}$ Department of Medicine, Medical Center East, Tokyo Women's Medical University ; ${ }^{4}$ Department of Kidney Center, Tokyo Women's Medical University

Keywords : phosphate binder, number of prescribed pills, medication adherence, serum phosphorus levels 〈Abstract〉

【Objectives】 To examine the influence of the prescribed phosphate binder pill burden on medication adherence and serum phosphorus levels in Japanese hemodialysis patients. 【Methods】 Adherence to phosphate binders was assessed using a questionnaire in 229 chronic hemodialysis patients that were being treated with phosphate binders. We analyzed the relationships between the number of monthly prescribed phosphate binder pills and adherence according to the questionnaire or other patient characteristics including the serum calcium, phosphorus, or intact parathyroid hormone level.【Results】 The median monthly pill burden was 210 pills, and $50 \%$ of the patients were receiving monotherapy. The higher pill burden group exhibited a younger age, a longer hemo-

永野 伸郎 医療法人社団日高会腎臟病治療センター/日高学術研究センター $\quad$ 个 370-0001 群馬県高崎市中尾町 886 Nobuo Nagano Tel : 027-362-6201 Fax :027-362-8996 E-mail : n_nagano@hidaka-kai.com

〔受付日：2016 年 2 月 23 日, 受理日：2016 年 5 月 4 日〕 
dialysis vintage, and higher serum phosphorus levels. A positive linear relationship was also observed between the number of phosphate binder pills and the serum phosphorus level. Approximately $30-40 \%$ of the patients were non-adherent. The patients that forgot to take the pills, had pills remaining, or wanted to reduce the number of pills they were taking exhibited a higher pill burden and higher serum phosphorus levels. In addition, the proportions of patients that had pills remaining or felt that they were taking many/too many pills rose as the number of prescribed pills increased. Furthermore, more non-adherent patients felt that they were taking many/ too many pills compared with the adherent patients.【Conclusion】 The prescription of a higher number of phosphate binder pills is associated with lower medication adherence and worse serum phosphorus control.

\section{緒言}

透析患者における高リン血症は，心血管病および死 亡の独立したリスク因子であり ${ }^{1 \sim 3)}$, リン吸着薬を服 用している透析患者は, 非服用患者と比較して, 死亡 リスクが低いことも報告されている ${ }^{4 \sim 6)}$. 一方, リン 吸着薬に対する服薬アドヒアランス良好者の割合は, その評価方法および定義により左右されるものの, 35〜 60\%と全般的に低いことが知られている ${ }^{7 \sim 11)}$. さ らには,リン吸着薬に対するアドヒアランスの低下 は，血清リン高值，副甲状腺ホルモン（parathyroid hormone : PTH) 高值, 生活の質 (quality of life : QOL）低下, 医療費増加と関連することも示されてい $3^{8 \sim 14)}$.

しかしながら，これらはいずれも欧米を中心とした 海外からの報告にとどまる，海外と日本とでは，処方 可能なリン吸着薬の種類, 規格, 剤形, 用法用量に加 え, 医療制度, ガイドライン, 透析環境, 患者の年齢, 透析歴, 体格, 食習慣, 治療遵守性などが異なるため, これらの海外データを本邦へ単純に外挿することに関 しては疑問の余地がある.

そこで今回，本邦における実態を把握する目的で， 当院の外来維持血液透析患者を対象にアンケート調查 を実施し, リン吸着薬の処方錠数が服薬アドヒアラン スおよび血清リンに対する影響を中心に検討した。

\section{I . 対象と方法}

\section{1. 対 象}

平成日高クリニック透析センターの維持血液透析患 者 539 名において, 入院中の 31 名, 改訂長谷川式簡易 知能評価スケール (HDS-R) により認知症・認知症疑 いと過去に判定された 49 名, 視力障害や上肢機能障害 による読み書き困難者 43 名を除いた 416 名に試験概要 を説明した. このうち, リン吸着薬非服用者およびア ンケート調查に非協力的・拒絶的態度を示す試験非適
格者を除き，本人の自著による試験参加同意が得られ た 295 名に対し，リン吸着薬に関するアンケート調查 を 2015 年 8 月下旬に実施した。全問に回答し，当該月 1 か月間の全日数にリン吸着薬が処方され，かつ 8 月 下旬の定期採血結果がある 229 名を解析対象とした (表 1).なお, 本研究は当院倫理委員会より付議不要 と判断されたため, 病院長に実施の許可を得た後に 行った.

\section{2. リン吸着薬に関するアンケート}

リン吸着薬に関する質問 4 問 $(\mathrm{Q} 1$ ～Q4) および服薬 アドヒアランスに関連する質問 6 問（Q5～Q10）（表 2) と, 将来のリン吸着薬への要望に関する質問 ${ }^{15)}$ から なる計 $11 の$ 質問票を作成し, 各質問にはチェック欄付 きの回答選択肢を設けた。アンケートは透析施行中に 回答してもらうか, あるいは本人の希望により持ち 帰った場合は次回来院時に回収した。

なお，質問 $\mathrm{Q} 5 ， \mathrm{Q} 9 ， \mathrm{Q} 10$ および将来のリン吸着薬 への要望に関する質問（結果示さず）は，8月下旬の 採血結果のない14名を加えた全243名を対象とした回 答者の割合を他誌に紹介済みである ${ }^{15)}$.

\section{3. リン吸着薬処方錠数}

アンケート調査時に当院にて処方中のリン吸着薬 は, 沈降炭酸カルシウム錠 $500 \mathrm{mg}$ 「三和」（三和化学 研究所), ホスレノール ${ }^{\circledR}$ 顆粒分包 $250 \mathrm{mg}$ (バイエル 薬品), リオナ ${ }^{\circledR}$ 錠 $250 \mathrm{mg}$ (鳥居薬品), レナジェル ${ }^{\circledR}$ 錠 $250 \mathrm{mg}$ (中外製薬), キックリン ${ }^{\circledR}$ カプセル $250 \mathrm{mg}$ (アステラス製薬) の 5 種 5 片形であった（現時点で炭 酸カルシウム製剤は 9 剂形が，炭酸ランタン製剤は 4 剂形が市販されており, 今後も剂形追加が予定されて いるリン吸着薬もある ${ }^{15)}$. 剂形は服薬アドヒアランス に影響するため ${ }^{15)}$ ，ここでは剂形および規格単位を特 定するために商品名を列挙し，その他の箇所では一般 名で表記)。全 229 名中, いずれかの単剂処方者は $50.2 \%, 2$ 剂併用処方者は 43.7\%，3 剂併用処方者は $5.9 \%$ あ゙あた。 また, 単剂処方で最も多いのが炭酸力 ルシウム製剤（全体の 35.8\%）であり，2 剂併用で最 も多いのが炭酸カルシウム製剤と炭酸ランタン製剤の 
表 1 全 229 人ならびにリン吸着薬月間処方錠数四分位別の患者背景

\begin{tabular}{|c|c|c|c|c|c|c|c|}
\hline \multirow[b]{2}{*}{ 項 目 } & \multirow[b]{2}{*}{ 単位 } & \multirow{2}{*}{$\begin{array}{l}\text { 全 体 } \\
229 \text { 人 }\end{array}$} & \multicolumn{5}{|c|}{ リン吸着薬 月間処方錠数四分位 } \\
\hline & & & $\begin{array}{c}\text { 第 } 1 \text { 四分位 } \\
58 \text { 人 }\end{array}$ & $\begin{array}{c}\text { 第 } 2 \text { 四分位 } \\
60 \text { 人 }\end{array}$ & $\begin{array}{c}\text { 第 } 3 \text { 四分位 } \\
54 \text { 人 }\end{array}$ & $\begin{array}{c}\text { 第 } 4 \text { 四分位 } \\
57 \text { 人 }\end{array}$ & $\begin{array}{l}\text { 統計 } \\
\text { (p 值) }\end{array}$ \\
\hline 性別（男性） & 人 $(\%)$ & $173(75.5 \%)$ & $41 \quad(23.7 \%)$ & $42(24.3 \%)$ & $42(24.3 \%)$ & $48(27.7 \%)$ & n.s. \\
\hline 年齢 & 歳 & $65.7(58.0-71.0)$ & $67.3(62.2-73.9)$ & $66.8(61.2-70.6)$ & $64.5(54.7-71.5)$ & $62.4(55.3-67.3)$ & 0.005 \\
\hline 透析歴 & & $6.6(2.9-12.7)$ & $4.2(1.8-10.3)$ & $5.9(2.5-11.0)$ & $6.9(3.5-17.4)$ & $8.7(5.8-16.2)$ & 0.009 \\
\hline 原疾患（DM） & 人 $(\%)$ & $92(40.2 \%)$ & $24(26.1 \%)$ & $27(29.3 \%)$ & $17(18.5 \%)$ & $24(26.1 \%)$ & n.s. \\
\hline 血清 Alb & $\mathrm{g} / \mathrm{dL}$ & $3.7(3.5-3.9)$ & $3.7(3.5-3.9)$ & $3.7(3.5-3.9)$ & $3.7(3.5-4.0)$ & $3.7(3.6-3.9)$ & n.s. \\
\hline 血清補正 Ca & $\mathrm{mg} / \mathrm{dL}$ & $8.77 \pm 0.56$ & $8.81 \pm 0.47$ & $8.70 \pm 0.56$ & $8.77 \pm 0.60$ & $8.81 \pm 0.61$ & n.s. \\
\hline 血清リン & $\mathrm{mg} / \mathrm{dL}$ & $5.15 \pm 1.00$ & $4.94 \pm 0.82$ & $4.99 \pm 0.97$ & $5.31 \pm 0.94$ & $5.37 \pm 1.19$ & 0.044 \\
\hline 血清 i-PTH & $\mathrm{pg} / \mathrm{mL}$ & $173(121-260)$ & $160(104-265)$ & $152(102-247)$ & $189(125-261)$ & $174(123-332)$ & n.s. \\
\hline 処方錠数 & 錠/月 & $210(105-315)$ & $84(56-84)$ & $168(168-189)$ & $263(252-294)$ & $420(336-504)$ & $<0.001$ \\
\hline
\end{tabular}

$\mathrm{DM}$ ：糖尿病性腎症, Alb：アルブミン, n.s. : 有意差なし

表 2 リン吸着薬に関するアンケートおよび各回答の患者数と割合

リン吸着薬に関する質問：Q1〜Q4,

服薬アドヒアランスに関連する質問：Q5〜Q10

\begin{tabular}{|c|c|c|c|c|c|c|c|}
\hline \multirow{4}{*}{ Q1 } & \multirow{4}{*}{$\begin{array}{l}\text { あなたが飲んでいるリン吸着薬の目的 } \\
\text { を理解していますか? } \\
\text { (1)全くわからない } \\
\text { (2)少しわかる } \\
\text { (3)わかる } \\
\text { (4)よくわかる } \\
\text { (5)空欄 }\end{array}$} & \multirow{2}{*}{\multicolumn{2}{|c|}{ （効果，必要性） }} & \multirow{4}{*}{ Q6 : } & \multicolumn{3}{|c|}{ リン吸着薬を飲み忘れてしまうことがありますか？ } \\
\hline & & & & & \multirow{2}{*}{$\begin{array}{l}\text { (1)飲み忘れしない } \\
\text { (2)飲み忘れる } \\
\text { (3)空欄 }\end{array}$} & \multirow{2}{*}{\begin{tabular}{r|}
38 人 \\
83 人 \\
8 人 \\
\end{tabular}} & \multirow{2}{*}{$\begin{array}{r}60.3 \% \\
36.2 \% \\
3.5 \%\end{array}$} \\
\hline & & \multirow{2}{*}{$\begin{array}{r}8 \text { 人 } \\
58 \text { 人 } \\
122 \text { 人 } \\
40 \text { 人 } \\
1 \text { 人 }\end{array}$} & \multirow{2}{*}{$\begin{array}{r}3.5 \% \\
25.3 \% \\
53.3 \% \\
17.5 \% \\
0.4 \%\end{array}$} & & & & \\
\hline & & & & & \multicolumn{3}{|c|}{$\begin{array}{l}\text { リン吸着薬を飲み忘れる場合のある方にその理由をお } \\
\text { たずねします。 }\end{array}$} \\
\hline Q2: & \multicolumn{3}{|c|}{$\begin{array}{l}\text { あなたが飲んでいるリン吸着薬の副作用を理解してい } \\
\text { ますか？ }\end{array}$} & & \multirow{2}{*}{$\begin{array}{l}\text { (1)仕事の都合 } \\
\text { (2)食生活が不規則 } \\
\text { (3)外出時の不携帯 } \\
\text { (4)その他+ 空欄 }\end{array}$} & \multirow{2}{*}{$\begin{array}{l}8 \text { 人 } \\
14 \text { 人 } \\
58 \text { 人 } \\
3 \text { 人 }\end{array}$} & \multirow{2}{*}{$\begin{array}{r}9.6 \% \\
16.9 \% \\
69.9 \% \\
3.6 \% \\
\end{array}$} \\
\hline & \multirow{3}{*}{$\begin{array}{l}\text { (1)全くわからない } \\
\text { (2)少しわかる } \\
\text { (3)わかる } \\
\text { (4)よくわかる } \\
\text { (5)空欄 }\end{array}$} & \multirow{3}{*}{$\begin{array}{l}66 \text { 人 } \\
79 \text { 人 } \\
70 \text { 人 } \\
12 \text { 人 } \\
2 \text { 人 }\end{array}$} & \multirow{3}{*}{$\begin{array}{r}28.8 \% \\
34.5 \% \\
30.6 \% \\
5.2 \% \\
0.9 \% \\
\end{array}$} & & & & \\
\hline & & & & Q8 : & \multicolumn{3}{|c|}{$\begin{array}{l}\text { 飲み残したり，飲み忘れたリン吸着薬が自宅にありま } \\
\text { すか？ }\end{array}$} \\
\hline & & & & & \multirow{2}{*}{$\begin{array}{l}\text { (1)まったくない } \\
\text { (2)あったが捨てている } \\
\text { (3)ある } \\
\text { (4)空欄 }\end{array}$} & \multirow{2}{*}{$\begin{array}{l}109 \text { 人 } \\
44 \text { 人 } \\
62 \text { 人 } \\
14 \text { 人 }\end{array}$} & \multirow{2}{*}{$\begin{array}{r}47.6 \% \\
19.2 \% \\
27.1 \% \\
6.1 \%\end{array}$} \\
\hline Q3 : & \multicolumn{3}{|c|}{$\begin{array}{l}\text { リン吸着薬の服薬に関して, 不安や抵抗があります } \\
\text { か？ }\end{array}$} & & & & \\
\hline & \multirow{2}{*}{$\begin{array}{l}\text { (1)ない } \\
\text { (2)少しある } \\
\text { (3)大いにある } \\
\text { (4)空欄 }\end{array}$} & \multirow{2}{*}{$\begin{array}{r}168 \text { 人 } \\
49 \text { 人 } \\
9 \text { 人 } \\
3 \text { 人 }\end{array}$} & \multirow{2}{*}{$\begin{array}{r}73.4 \% \\
21.4 \% \\
3.9 \% \\
1.3 \% \\
\end{array}$} & Q9: & \multicolumn{3}{|c|}{$\begin{array}{l}\text { あなたが飲んでいるリン吸着薬の } 1 \text { 回の量は適量だと } \\
\text { 思いますか？ }\end{array}$} \\
\hline & & & & & \multirow{3}{*}{$\begin{array}{l}\text { (1)少ない } \\
\text { (2)丁度よい } \\
\text { (3)多い } \\
\text { (4)とても多い } \\
\text { (5)空欄 }\end{array}$} & \multirow{3}{*}{$\begin{array}{r}3 \text { 人 } \\
151 \text { 人 } \\
47 \text { 人 } \\
6 \text { 人 } \\
22 \text { 人 }\end{array}$} & \multirow{3}{*}{$\begin{array}{r}1.3 \% \\
65.9 \% \\
20.5 \% \\
2.6 \% \\
9.6 \% \\
\end{array}$} \\
\hline Q4： & $\begin{array}{l}\text { あなたが飲んでいるリン吸着薬の内服旺 } \\
\text { ング）を理解していますか? }\end{array}$ & 寺間(飲む & タイミ & & & & \\
\hline & \multirow{2}{*}{$\begin{array}{l}\text { (1)理解していない } \\
\text { (2)理解している } \\
\text { (3)空欄 }\end{array}$} & \multirow{2}{*}{$\begin{array}{r}25 \text { 人 } \\
201 \text { 人 } \\
3 \text { 人 }\end{array}$} & \multirow{2}{*}{$\begin{array}{r}10.9 \% \\
87.8 \% \\
1.3 \% \\
\end{array}$} & & & & \\
\hline & & & & Q10: & \multicolumn{3}{|c|}{ リン吸着薬を飲む量を減らしたいと思いますか？ } \\
\hline Q5 : & \multicolumn{3}{|l|}{ 毎日の服薬状況を教えてください. } & & \multirow{3}{*}{$\begin{array}{l}\text { (1)減らしたいと思わない } \\
\text { (2)どちらとも思わない } \\
\text { (3)減らしたいと思う } \\
\text { (4)空欄 }\end{array}$} & \multirow{3}{*}{$\begin{array}{l}56 \text { 人 } \\
80 \text { 人 } \\
84 \text { 人 } \\
9 \text { 人 }\end{array}$} & $\begin{array}{l}24.5 \% \\
34.9 \%\end{array}$ \\
\hline & $\begin{array}{l}\text { (1)決められた量を全部飲みきっている } \\
\text { (2)少し飲み残しがある } \\
\text { (3)半分くらい飲み残しがある }\end{array}$ & $\begin{array}{c}158 \text { 人 } \\
65 \text { 人 } \\
6 \text { 人 }\end{array}$ & $\begin{array}{r}69.0 \% \\
28.4 \% \\
2.6 \%\end{array}$ & & & & $\begin{array}{r}36.7 \% \\
3.9 \%\end{array}$ \\
\hline & $\begin{array}{l}\text { (4)ほとんど飲んでいない/まったく飲 } \\
\text { んでいない }\end{array}$ & 0 人 & $0 \%$ & & & & \\
\hline
\end{tabular}

併用処方（全体の $27.1 \%$ ）であった.

当該月の月間処方記録に基づき，患者 1 人当たり 1 か月間のリン吸着薬各種の処方錠数を合計し, リン吸 着薬月間処方錠数とした，なお，算出にあたり，顆粒 製剤 1 包は 1 錠とした.

\section{4. 解 析}

リン吸着薬月間処方錠数と血清補正 $\mathrm{Ca}$, リン, intact PTH (i-PTH) との間の単相関関係を検討した （図 1).また，月間処方錠数を四分位群に分け，患者 背景, 血清アルブミン (Alb), 補正 $\mathrm{Ca}$, リン, i-PTH を解析するとともに（表 1), アドヒアランス関連の質 
血清補正Ca値 $(\mathrm{mg} / \mathrm{dL})$

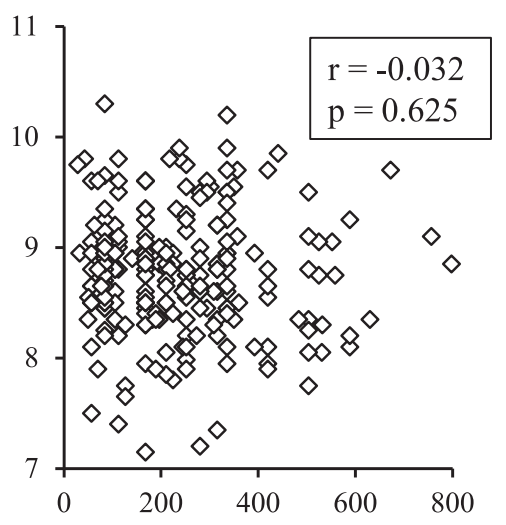

処方錠数 (錠/月)
血清リン值 $(\mathrm{mg} / \mathrm{dL})$

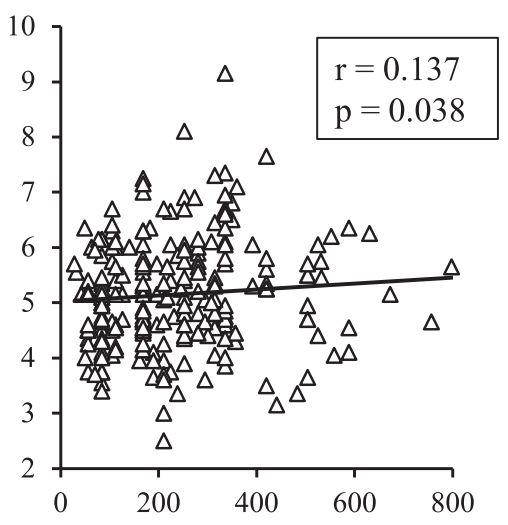

処方錠数 (錠/月)
血清i-PTH値 $(\mathrm{pg} / \mathrm{mL})$

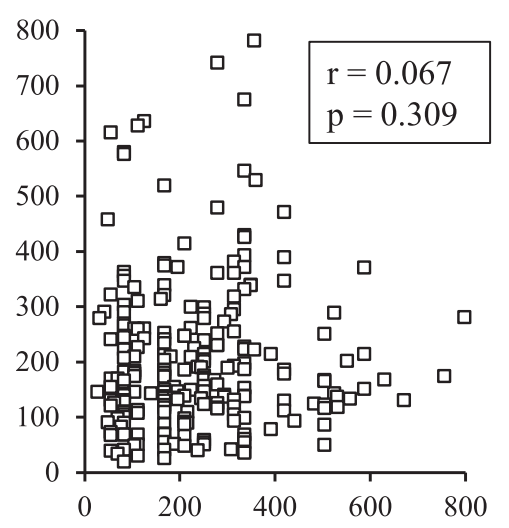

処方錠数 (錠/月)

図 1 リン吸着処方錠数と血清補正 $\mathrm{Ca}$, リン, $\mathrm{i}-\mathrm{PTH}$ 値との間の単相関関係

問（Q5，Q6，Q8，Q9，Q10）に関して，各回答者の 割合を比較した（表 4)。さらには,アドヒアランス関 連質問の回答別に, 患者年齢, 透析歴, 血清補正 $\mathrm{Ca}$, リン, i-PTH，錠数を比較した（表 3).

比較検定に際し，空欄回答者は解析から除外し，少 人数が選択した選択肢抢よび程度は異なるものの同様 の概念からなる選択肢同士の回答を組み合わせること で，2群間の比較を実施した（表 3，表 4).

5. 統 計

Shapiro-Wilk 検定により標本分布の正規性を判定 後, 同じ群に属する標本あるいは比較する対となる標 本がいずれも正規分布する場合は, 平均值士標準偏差 で, その他の場合は, 中央值（第 1 四分位数-第 3 四分 位数) で表示した。連続変数の比較は標本分布, 群数 に従い, 2 標本 $t$ 検定, Mann-Whitney $U$ 検定，一元 配置分散分析, Kruskal-Wallis 検定を適宜実施した. 離散変数は $\chi^{2}$ 検定, 2 変量の相関は Spearman の相関 係数を用いた，統計解析ソフトはSPSS Statics 21 （IBM）を使用し，いずれも $\mathrm{p}<0.05$ を統計学的有意差 ありとした。

\section{II. 結 果}

\section{1. 患者背景ならびに処方錠数}

全解析対象者の $75.5 \%$ が男性, 年齢中央值は 65.7 歳, 糖尿病性（diabetes mellitus：DM）腎症は $40.2 \%$ で あった（表 1). 96.5\%が血液透析，3.5\%が血液滤過透 析を週 3 回安定して施行中であり, 透析条件は, 透析 時間（ $<4$ 時間； $12.6 \% ， 4$ 時間； $85.6 \% ， 4$ 時間 $<;$ $1.7 \%)$, 血流量 ( $<200 \mathrm{~mL} / \mathrm{min} ; 14.4 \%, 200 \mathrm{~mL} / \mathrm{min}$; $44.5 \%, 200 \mathrm{~mL} / \mathrm{min}<; 41.0 \%)$, 透析液 Ca 濃度 $(2.5$
$\mathrm{mEq} / \mathrm{L} ; 76.0 \%, 3 \mathrm{mEq} / \mathrm{L} ; 24 \%)$ であり, シナカル セ卜塩酸塩の処方割合は $39.7 \%$ あった。

患者 1 名当たり 1 か月間のリン吸着薬処方錠数の中 央值は 210 錠であった（表 1). 四分位群別解析の結 果, 処方錠数と, 性別, DM 腎症の割合, 血清 Alb, 補正 $\mathrm{Ca}, \mathrm{i}-\mathrm{PTH}$ との間に関連性は認められなかった。 一方，処方錠数の増加にともない，年齢が低下し，透 析歴が長くなり, 血清リンが高値を呈した. 同様に, 処方錠数と血清補正 Ca および $\mathrm{i}-\mathrm{PTH}$ との間に単相関 関係は認められなかったが，処方錠数と血清リンとの 間には, 有意な正の単相関関係が認められた（図 1). また, 年齢と血清 Alb との間に有意な負の単相関関係 が認められた $(\mathrm{r}=-0.369, \mathrm{p}<0.001)$.

\section{2. アンケート結果}

\section{1）リン吸着薬に関する質問}

アンケートの質問内容の全文，各質問に対する回答 選択肢と回答者数ならびに全 229 名に占める各回答者 の割合（\%）を表 2 に示す． 約 7 割の患者がリン吸着 薬の目的（効果，必要性）を「わかる・よくわかる」 と回答したのに対し $(\mathrm{Q} 1)$, 副作用の理解に関し「わ かる・よくわかる」と回答した患者はその半分程度で あった (Q2)。約 1/4の患者がリン吸着薬服用に関し て不安や抵抗が「少しある・大いにある」と回答し (Q3), 約 1 割の患者が服薬タイミングを理解していな かった (Q4).

\section{2）服薬アドヒアランスに関連する質問}

「決められた量を全部飲みきっている」と回答した患 者は約 7 割であった（Q5)。服薬アドヒアランスに関 する内容を異なる表現あるいは視点から質問した結 果,「飲み忘れしない」患者は約 6 割に低下し (Q6), 残薬が自宅に「あったが捨てている・ある」患者は 5 
表 3 服薬アドヒアランス関連の質問に対する回答（2 群に分類）と患者背景

\begin{tabular}{|c|c|c|c|c|c|c|c|c|}
\hline & & & $\begin{array}{l}\text { 年 齢 } \\
\text { (歳) }\end{array}$ & $\begin{array}{c}\text { 透析歴 } \\
\text { (年) }\end{array}$ & $\begin{array}{l}\text { 血清補正 Ca } \\
(\mathrm{mg} / \mathrm{dL})\end{array}$ & $\begin{array}{l}\text { 血清リン } \\
(\mathrm{mg} / \mathrm{dL})\end{array}$ & $\begin{array}{c}\text { 血清 i-PTH } \\
(\mathrm{pg} / \mathrm{mL})\end{array}$ & $\begin{array}{l}\text { 錠 数 } \\
\text { (錠/月) }\end{array}$ \\
\hline \multirow[t]{3}{*}{ Q5 : } & \multicolumn{2}{|c|}{ 毎日の服薬状況を教えてください. } & & & & & & \\
\hline & $\begin{array}{l}\text { (1)決められた量を全部飲み } \\
\text { きっている }\end{array}$ & 158 人 & $\begin{array}{l}66.9(60.7- \\
72.6)\end{array}$ & $\begin{array}{l}6.5(2.9- \\
11.5)\end{array}$ & $8.76 \pm 0.52$ & $5.07 \pm 0.95$ & $157(115-247)$ & $203(84-315)$ \\
\hline & $\begin{array}{l}\text { (2)少し飲み残しがある } \\
\text { (3)半分くらい飲み残しがあ } \\
\text { る }\end{array}$ & 71 人 & $\begin{array}{l}62.2(52.6- \\
66.7)^{* * *} *\end{array}$ & $\begin{array}{l}7.4\left(2.8^{-}\right. \\
17.5)\end{array}$ & $8.79 \pm 0.63$ & $5.33 \pm 1.09$ & $191 \quad(126-327)$ & $245(168-336)$ \\
\hline \multirow[t]{3}{*}{ Q6: } & \multicolumn{2}{|c|}{$\begin{array}{l}\text { リン吸着薬を飲み忘れてしまうこと } \\
\text { がありますか? }\end{array}$} & & & & & & \\
\hline & (1)飲み忘れしない & 138 人 & $\begin{array}{l}66.8(59.9- \\
72.6)\end{array}$ & $\begin{array}{l}5.9\left(2.5^{-}\right. \\
10.8)\end{array}$ & $8.80 \pm 0.53$ & $5.01 \pm 0.91$ & $162(117-247)$ & $186(105-315)$ \\
\hline & (2)飲み忘れる & 83 人 & $\begin{array}{l}62.7(53.7- \\
67.7)^{* * *}\end{array}$ & $\begin{array}{l}8.4\left(3.5^{-}\right. \\
16.8)^{*}\end{array}$ & $8.73 \pm 0.63$ & $5.41 \pm 1.12^{*}$ & $190(124-289)$ & $252(168-336)^{*}$ \\
\hline \multirow[t]{3}{*}{ Q8 : } & \multicolumn{2}{|c|}{$\begin{array}{l}\text { 飲み残したり，飲み忘れたリン吸着 } \\
\text { 薬が自宅にありますか? }\end{array}$} & & & & & & \\
\hline & (1)まったくない & 109 人 & $\begin{array}{l}68.6(64.2- \\
72.9)\end{array}$ & $\begin{array}{l}5.9(2.7- \\
11.5)\end{array}$ & $8.78 \pm 0.50$ & $5.02 \pm 0.98$ & $154(117-247)$ & $182(84-294)$ \\
\hline & $\begin{array}{l}\text { (2)あったが捨てている } \\
\text { (3)ある }\end{array}$ & 106 人 & $\begin{array}{l}61.8(53.9- \\
67.0)^{* * *}\end{array}$ & $\begin{array}{l}6.8(3.2- \\
15.6)\end{array}$ & $8.74 \pm 0.59$ & $5.31 \pm 1.04^{*}$ & $182(123-290)$ & $252(168-336) * *$ \\
\hline \multirow[t]{3}{*}{ Q9 } & \multicolumn{2}{|c|}{$\begin{array}{l}\text { あなたが飲んでいるリン吸着薬の } 1 \\
\text { 回の量は適量だと思いますか? }\end{array}$} & & & & & & \\
\hline & $\begin{array}{l}\text { (1)少ない } \\
\text { (2)丁度よい }\end{array}$ & 154 人 & $\begin{array}{l}65.7\left(57.6^{-}\right. \\
70.8)\end{array}$ & $\begin{array}{l}6.5(2.7- \\
13.8)\end{array}$ & $8.82 \pm 0.55$ & $5.10 \pm 0.96$ & $169(112-260)$ & $193(105-294)$ \\
\hline & $\begin{array}{l}\text { (3)多い } \\
\text { (4)とても多い }\end{array}$ & 53 人 & $\begin{array}{l}64.0\left(56.5^{-}\right. \\
69.7)^{-}\end{array}$ & $\begin{array}{l}7.4(3.1- \\
15.6)\end{array}$ & $8.58 \pm 0.58$ & $5.31 \pm 1.11$ & $169(125-280)$ & $308(196-420) * * *$ \\
\hline \multirow[t]{3}{*}{ Q10 : } & \multicolumn{2}{|c|}{$\begin{array}{l}\text { リン吸着薬を飲む量を減らしたいと } \\
\text { 思いますか? }\end{array}$} & & & & & & \\
\hline & $\begin{array}{l}\text { (1)減らしたいと思わない } \\
\text { (2) どちらとも思わない }\end{array}$ & 136 人 & $\begin{array}{l}65.8\left(58.0^{-}\right. \\
70.8)\end{array}$ & $\begin{array}{l}6.8(3.1- \\
14.6)\end{array}$ & $8.77 \pm 0.53$ & $5.00 \pm 0.99$ & $157(109-249)$ & $189(105-308)$ \\
\hline & (3)減らしたいと思う & 84 人 & $\begin{array}{l}64.7\left(57.1^{-}\right. \\
70.4)\end{array}$ & $\begin{array}{l}6.4\left(2.6^{-}\right. \\
11.3)\end{array}$ & $8.80 \pm 0.60$ & $5.31 \pm 0.98^{*}$ & $171(123-274)$ & $252(147-343)^{*}$ \\
\hline
\end{tabular}

割程度であった（Q8）。飲み忘れる患者の理由で最も 多いのが,「外出時の不携帯」であり約 7 割を占めた (Q7). 約 1/4 の患者がリン吸着薬の服薬量を「多い. とても多い」と感じており (Q9)，1/3 以上の患者が 「減らしたいと思う」と回答した $(\mathrm{Q} 10)$.

\section{3. 服薬アドヒアランスと患者背景}

アドヒアランスに関する 3 つの質問（Q5，Q6，Q8) に打いて，それぞれ「少し・半分くらい飲み残しがあ る」,「飲み忘れる」, 残薬が「あったが捨てている・あ る」と回答したアドヒアランス不良者は，「全部飲み きっている」,「飲み忘れしない」, 残薬が「まったくな い」と回答したアドヒアランス優良者と比較して, 年 齢が若いことが共通して確認された（表 3)。また，ア ドヒアランス不良者は透析歴が長い傾向にあり，「飲 み忘れる」患者は透析歴が有意に長かった。血清補正 $\mathrm{Ca}$ および $\mathrm{i}-\mathrm{PTH}$ は，アドヒアランス関連の質問の 2 群間比較において，いずれも有意差を示さなかった
が, 血清i-PTHはアドヒアランス不良者で高值傾向で あった。

一方，血清リンおよび処方錠数は，「飲み忘れる」患 者, 残薬が「あったが捨てている・ある」患者, 飲む 量を「減らしたいと思う」患者に扔いて有意に高值で あった．また，飲む量が「多い・とても多い」と回答 した患者の血清リンは高い傾向にあり，かつ錠数は有 意に多かった。

\section{4. 処方錠数と服薬アドヒアランス}

処方錠数とアドヒアランスの関係をより詳細に解析 する目的で，月間処方錠数を四分位群に分け，表 3 と 同様に質問の回答を 2 群に分けて患者割合を比較した (表 4). その結果, 処方錠数が増加するに従い, 残薬 が「あったが捨てている・ある」, 飲む量が「多い・と ても多い」とする患者が有意に増加した，また，有意 差は認められなかったものの, 錠数増加に従い,「飲み 忘れる」, 飲む量を「減らしたいと思う」患者が増加す 
表 4 リン吸着薬月間処方錠数四分位別の服薬アドヒアランス関連の質問に対する回答（2群に分類）者の割合

\begin{tabular}{|c|c|c|c|c|c|}
\hline & \multicolumn{4}{|c|}{ リン吸着薬 月間処方錠数四分位 } & \multirow[b]{2}{*}{ 統 計 } \\
\hline $\begin{array}{l}\text { 四分位群 } \\
\text { 錠 数 (錠/月) } \\
\text { 人 数 }\end{array}$ & $\begin{array}{c}\text { 第 } 1 \text { 四分位 } \\
84(56-84) \\
58 \text { 人 }\end{array}$ & $\begin{array}{c}\text { 第 } 2 \text { 四分位 } \\
168 （ 168-189) \\
60 \text { 人 }\end{array}$ & $\begin{array}{c}\text { 第 } 3 \text { 四分位 } \\
263(252-294) \\
54 \text { 人 }\end{array}$ & $\begin{array}{c}\text { 第 } 4 \text { 四分位 } \\
420 （ 336-504) \\
57 \text { 人 }\end{array}$ & \\
\hline \multicolumn{6}{|l|}{ Q5：毎日の服薬状況を教えてください. } \\
\hline (1)決められた量を全部飲み切っている & 46 人 $(29.1 \%)$ & 40 人 $(25.3 \%)$ & 34 人 $(21.5 \%)$ & 38 人 $(24.1 \%)$ & \multirow[b]{2}{*}{$\mathrm{p}=0.251$} \\
\hline $\begin{array}{l}\text { (2)少し飲み残しがある } \\
\text { (3)半分くらい飲み残しがある }\end{array}$ & 12 人 $(16.9 \%)$ & 20 人 $(28.2 \%)$ & 20 人 $(28.2 \%)$ & 19 人 $(26.8 \%)$ & \\
\hline \multicolumn{6}{|c|}{ Q6：リン吸着薬を飲み忘れてしまうことがありますか？ } \\
\hline (1)飲み忘れしない & 39 人 $(28.3 \%)$ & 40 人 $(29.0 \%)$ & 32 人 $(23.2 \%)$ & 27 人 $(19.6 \%)$ & \multirow{2}{*}{$\mathrm{p}=0.055$} \\
\hline (2)飲み忘れる & 16 人 $(19.3 \%)$ & 18 人 $(21.7 \%)$ & 20 人 $(24.1 \%)$ & 29 人 $(34.9 \%)$ & \\
\hline \multicolumn{6}{|c|}{ Q8：飲み残したり，飲み忘れたリン吸着薬が自宅にありますか？ } \\
\hline (1)まったくない & 36 人 $(33.0 \%)$ & 29 人 $(26.6 \%)$ & 24 人 $(22.0 \%)$ & 20 人 $(18.3 \%)$ & \multirow[b]{2}{*}{$\mathrm{p}=0.038$} \\
\hline $\begin{array}{l}\text { (2)あったが捨てている } \\
\text { (3)ある }\end{array}$ & 20 人 $(18.9 \%)$ & 26 人 $(24.5 \%)$ & 26 人 $(24.5 \%)$ & 34 人 $(32.1 \%)$ & \\
\hline \multicolumn{6}{|c|}{ Q9：あなたが飲んでいるリン吸着薬の 1 回の量は適量だと思いますか？ } \\
\hline $\begin{array}{l}\text { (1)少ない } \\
\text { (2)丁度よい }\end{array}$ & 42 人 $(27.3 \%)$ & 45 人 $(29.2 \%)$ & 37 人 $(24.0 \%)$ & 30 人 $(19.5 \%)$ & \multirow{2}{*}{$\mathrm{p}=0.001$} \\
\hline $\begin{array}{l}\text { (3)多い } \\
\text { (4)とても多い }\end{array}$ & 6 人 $(11.3 \%)$ & 9 人 $(17.0 \%)$ & 15 人 $(28.3 \%)$ & 23 人 $(43.4 \%)$ & \\
\hline \multicolumn{6}{|c|}{ Q10：リン吸着薬を飲む量を減らしたいと思いますか？ } \\
\hline $\begin{array}{l}\text { (1)減らしたいと思わない } \\
\text { (2)どちらとも思わない }\end{array}$ & 38 人 $(27.9 \%)$ & 40 人 $(29.4 \%)$ & 30 人 $(22.1 \%)$ & 28 人 $(20.6 \%)$ & \multirow[t]{2}{*}{$\mathrm{p}=0.085$} \\
\hline (3)減らしたいと思う & 16 人 $(19.0 \%)$ & 18 人 $(21.4 \%)$ & 22 人 $(26.2 \%)$ & 28 人 $(33.3 \%)$ & \\
\hline
\end{tabular}

\section{る傾向が認められた。}

また,「決められた量を全部飲みきっている」と回答 したアドヒアランス優良者 158 人中 26 人 (16.5\%) が 飲む量が「多い・とても多い」と回答したのに対して, 「少し・半分くらい飲み残しがある」と回答したアドヒ アランス不良者 71 人中 27 人 $(38.0 \%)$ が「多い・と ても多い」と回答した $(\mathrm{p}=0.001)$.

\section{III. 考察}

透析患者は多くの合併症を併発するためにポリ ファーマシー (多剤処方) 下にあり ${ }^{8,16)}$ ，その中でも処 方錠数の約半数をリン吸着薬が占めるとされる ${ }^{8)}$. 今 回，当院の患者 1 名当たりの月間処方錠数の中央值は 210 錠であり, 1 日当たり約 7 錠のリン吸着薬が処方さ れている計算となる。この值は, DOPPS（Dialysis Outcomes and Practice Patterns Study) における日 本のデータ $(1 \text { 日平均 } 6.7 \text { 錠 })^{11)}$ と近い值であり, 当院 のリン吸着薬処方実態は他施設と比較した際も平均的 であると推察される。そのような中, 今回, 年齢が若 い患者, 透析歴が長い患者, 血清リンが高值の患者で より多くの錠数が処方されていることが判明した．本
結果は，DOPPS における世界 12 か国のデータ11) と符 合する.

アンケートの結果,「決められた量を全部飲みきっ ている」と回答した患者は $69 \%$ であり，「飲み忘れし ない」と回答した患者は $60 \%$ であった. したがって現 実的には，当院におけるアドヒアランス優良者は 60〜 70\%であり，逆に不良者は 30～40\%と推定される．本 割合も DOPPS の日本のデータ（過去 1 か月間処方さ れた量をすべて飲む患者割合；65\%）とほほ同じであ る ${ }^{11)}$. 今回,「少し・半分くらい飲み残しがある」患者 で年齢は若く，血清リンは高值傾向であり，錠数も多 い傾向であった，また，「飲み忘れる」，残薬が「あっ たが捨てている・ある」患者は，年歯が若く，血清り ンが高く，処方錠数は多かった．さらには，本現象は 処方錠数の増加にともない,「飲み忘れる」患者割合が 増える傾向にあり，残薬が「あったが捨てている・あ る」患者割合が増加することでも確認された。年齢が 若いこととアドヒアランス不良, 錠数増加とアドヒア ランス不良, アドヒアランス不良と血清リン管理不良 が関連することは, 海外の先行研究結果と部分的に一 致する ${ }^{7 \sim 13)}$. 今回, 処方錠数と静的栄養指標である血 清 Alb との間に関連は認められなかったものの, 年齢 
は血清 Alb と負の相関を示した．食品中の蛋白質含量 とリン含量は高い正相関関係にあり ${ }^{17)}$ ，透析患者にお いて，食事に抢ける蛋白質摂取量の指標である標準化 蛋白異化率 (nPCR) は血清リンと正相関する ${ }^{18)}$. し たがって, 今回は食事調查を実施していないものの, 年齢が若い患者は活動性が高く食事リン摂取量が多く なり, 多くのリン吸着薬の処方に繋がっている可能性 が考えられる. また, 今回の観察研究の結果からは, 処方錠数増加がアドヒアランス低下を招き血清リン上 昇に繋がったのか，アドヒアランス低下による血清リ ン上昇が処方錠数増加を招いたのかの因果関係を論ず ることはできないものの，いずれにせよかかる悪循環 が背景にあるものと推察される.ささらには, 今回, 有 意ではないものの, 透析歴は血清リンと正相関する傾 向を示した $(r=0.118, p=0.075)$. したがって, 処方 錠数増加に従い透析歴が長くなる現象の背景にも, 透 析歴が長い患者は「飲み忘れる」患者が多いことが一 因となっている可能性も考えられた。

今回の興味深い結果として, リン吸着薬の飲む量 を,「多い・とても多い」と感ずる患者ならびに「減ら したいと思う」患者は，処方錠数が多かった．また，

処方錠数が増加するにつれ，これらの患者割合が増加 した，さらには，アドヒアランス不良者は飲む量を「多 い・とても多い」と回答する割合が高かった。このよ うに服薬アドヒアランスには, 患者のリン吸着薬処方 錠数に対する感じ方拉よび減量に対する希望が背景に 存在していることが改めて定量的に確認された。 今回 のアンケートを通じて定量化されたとおり, リン吸着 薬の効果, 必要性, 副作用に関しての理解が低く, リ ン吸着薬に対する不安や抵抗を有する患者が数割いる のが当院の現状である．今後は食事指導の徹底に加え て, リン吸着薬の必要性・重要性を再認識してもらう ための患者教育を充実させるとともに, 医師, 看護師, 薬剤師，栄養士を巻き込んでの服薬アドヒアランス向 上のためのシステム構築が求められる ${ }^{19 \sim 22) . ~}$

本研究の限界として, 第一に, 解析対象患者数は比 較的多いものの, 単一施設研究であることがあげられ る. 当院では処方権を有する19名の主治医が個々の判 断で薬剂処方を調整しているため, 医師間の処方バイ アスはある程度均等化されているものと考えられる。

一方, 当院で処方されているリン吸着薬は 5 種類 5 郕 形にとどまるため, これらの郕形の処方下に限定され た結果となっている。したがって, 炭酸カルシウム製 剤の $250 \mathrm{mg}$ 錠や細粒製剂, 炭酸ランタン製剂のチ工 アブル錠，スクロオキシ水酸化鉄製剂などの他種他剤 形が処方されている患者に外挿困難な点が課題であ
る. 第二に，5種類のリン吸着薬間で服薬アドヒアラ ンスはそれぞれ異なると考えられるが，今回は総錠数 の解析結果である点があげられる。単一製剂処方者に おける各製剤間の比較や併用処方者における各製剂の 組み合わせごとの解析などは, 各製剤間で処方人数に ばらつきが大きく，例数不十分につき実施不能であっ た. 第三に, 認知症患者を含めアンケートが不適切と 判断した患者および拒否した患者は, アンケート回答 者よりも服薬アドヒアランスが低い可能性が推察され る.しかしながら，このようなサンプルセレクション バイアスをなくすためには，全数調査をしなければな らず，一般臨床現場においては実施困難と考えられ る. 最後に, 服薬アドヒアランスに関する質問の回答 選択肢が定性的であったため, 2 群間比較にとどまり， より詳細な解析が実施できなかったことがあげられ る. 今後は残薬の錠数カウントや処方どおりに服薬し た日数の割合などの定量的な指標を用い ${ }^{8,13)}$, 種々の 郕形を採用している施設間での多施設共同研究によ り, 本邦でのエビデンスを蓄積していくことが課題で あろう。

\section{結＼cjkstart語}

日本人透析患者の血清リン高値の背景に, リン吸着 薬処方錠数増加と服薬アドヒアランス低下が関連する 悪循環が存在する.

謝辞：アンケート調査にご協力くださいました透析患者の 皆様に深く感謝申しあげます。 また, アンケート調査の実 施ならびに回収にご協力いただきました透析スタッフの皆 様に感謝いたします。

\section{文献}

1) Block GA, Klassen PS, Lazarus JM, Ofsthun N, Lowrie EG, Chertow GM. Mineral metabolism, mortality, and morbidity in maintenance hemodialysis. J Am Soc Nephrol 2004; 15: 2208-18.

2) Slinin Y, Foley RN, Collins AJ. Calcium, phosphorus, parathyroid hormone, and cardiovascular disease in hemodialysis patients: the USRDS waves 1, 3, and 4 study. J Am Soc Nephrol 2005; 16: 1788-93.

3) Kalantar-Zadeh K, Kuwae N, Regidor DL, et al. Survival predictability of time-varying indicators of bone disease in maintenance hemodialysis patients. Kidney Int 2006; 70: 771-80.

4) Isakova T, Gutiérrez OM, Chang Y, et al. Phosphorus binders and survival on hemodialysis. J Am Soc Nephrol 2009; 20: 388-96. 
5) Lopes AA, Tong L, Thumma J, et al. Phosphate binder use and mortality among hemodialysis patients in the Dialysis Outcomes and Practice Patterns Study (DOPPS): evaluation of possible confounding by nutritional status. Am J Kidney Dis 2012； 60: 90-101.

6) Cannata-Andía JB, Fernández-Martín JL, Locatelli F, et al. Use of phosphate-binding agents is associated with a lower risk of mortality. Kidney Int 2013; 84 : 998-1008.

7) Karamanidou C, Clatworthy J, Weinman J, Horne R. A systematic review of the prevalence and determinants of nonadherence to phosphate binding medication in patients with end-stage renal disease. BMC Nephrol 2008; 9: 2.

8) Chiu YW, Teitelbaum I, Misra M, de Leon EM, Adzize T, Mehrotra R. Pill burden, adherence, hyperphosphatemia, and quality of life in maintenance dialysis patients. Clin J Am Soc Nephrol 2009; 4: 1089-96.

9) Arenas MD, Malek T, Gil MT, Moledous A, AlvarezUde F, Reig-Ferrer A. Challenge of phosphorus control in hemodialysis patients: a problem of adherence? J Nephrol 2010; 23: 525-34.

10) Martins MT, Silva LF, Kraychete A, et al. Potentially modifiable factors associated with non-adherence to phosphate binder use in patients on hemodialysis. BMC Nephrol 2013; 14: 208.

11) Fissell RB, Karaboyas A, Bieber BA, et al. Phosphate binder pill burden, patient-reported non-adherence, and mineral bone disorder markers: Findings from the DOPPS. Hemodial Int 2016；20：38-49.

12) Hung KY, Liao SC, Chen TH, Chao MC, Chen JB. Adherence to phosphate binder therapy is the primary determinant of hyperphosphatemia incidence in patients receiving peritoneal dialysis. Ther Apher Dial 2013; 17: 72-7.
13) Wang S, Alfieri T, Ramakrishnan K, Braunhofer P, Newsome BA. Serum phosphorus levels and pill burden are inversely associated with adherence in patients on hemodialysis. Nephrol Dial Transplant 2014; 29: 2092-9.

14) Ramakrishnan $K$, Braunhofer $P$, Newsome B, et al. The economic impact of improving phosphate binder therapy adherence and attainment of guideline phosphorus goals in hemodialysis patients: a Medicare cost-offset model. Adv Ther 2014；31: 1272-86.

15）永野伸郎, 高橋伴彰, 石田秀岐, 伊藤恭子, 安藤哲郎, 筒井貴朗. リン吸着薬の製剤工夫と服薬アドヒアラン ス. Nephrology Frontier 2015；14：316-21.

16) Manley HJ, Garvin CG, Drayer DK, et al. Medication prescribing patterns in ambulatory haemodialysis patients: comparisons of USRDS to a large not-forprofit dialysis provider. Nephrol Dial Transplant 2004；19：1842-8.

17）小岩文彦．透析患者の栄養と食事療法. 昭和医会誌 2010；2: 121-5.

18）石村栄治, 奥野仙二, 加藤陽子, 西沢良記. 栄養障害 と低リン血症. 透析会誌 2011；44：49-52.

19）門脇大介, 佐藤みのり, 和泉智, 平田純生. 透析患者 の予後・QOL を改善する薬物適正使用. 透析会誌 2008; 41: 170-1.

20) Toussaint ND, Pedagogos E, Beavis J, Becker GJ, Polkinghorne KR, Kerr PG. Improving CKD-MBD management in haemodialysis patients: barrier analysis for implementing better practice. Nephrol Dial Transplant 2011; 26: 1319-26.

21）水内恵子. 透析チーム医療に抢ける薬剤師の役割一看 護師の立場から一. 透析会誌 2012；45：131-3.

22) Covic A, Rastogi A. Hyperphosphatemia in patients with ESRD: assessing the current evidence linking outcomes with treatment adherence. BMC Nephrol 2013; 14: 153. 